脳・脊骾の穿通動脈の機能解剖一中枢神経系の分節構築の観点から一

\author{
小宮山 雅樹
}

大阪市立総合医療センター脳血管内治療科

\title{
Functional Anatomy of the Perforating Arteries of the Brain and Spinal Cord : From the Viewpoint of Segmental Structures of the Central Nerv- ous System
}

\author{
Masaki Komiyama, M.D. \\ Department of Neuro-Intervention, Osaka City General Hospital
}

Embryologically, the neural tube develops in a segmental fashion. It consists of neuromeres along the cranio caudal axis. Segmentation of the spinal cord follows the development of mesodermal somites, of which the number of the somites is unique to the individual species, but the number of the rhombomeres of the brain stem is fixed to either 7 or 8 irrespective of the species. Classic telencephalic topological subdivisions determined by the cytoarchitecture have proven to be similar to histogenetic units defined by regulatory genes expressed in each neuromere. The vascular system of the central nervous system develops respecting these segmentally-arranged histogenetic units.

Basic arterial angioarchitecture of the spinal cord, brain stem, and brain consist of both centrifugal and centripetal perforating arteries in each histogenetic unit. That is, the central (ventral) perforating arteries supply the ipsilateral parenchyma centrifugally, and the peripheral (dorsal) perforating arteries of the vasa corona of the spinal cord, short/long circumferential arteries of the brain stem, and anterior/middle/posterior cerebral arteries of the brain perfuse the parenchyma centripetally. In this manner, the angioarchitecture of the central nervous system is organized on the basis of the 3 -dimensional patterning of the neural structure.

(Received August 8, 2014; accepted August 18, 2014)

Key words : anatomy, angioarchitecture, neuromere, histogenetic unit, perforating artery

Jpn J Neurosurg（Tokyo）24:4-11, 2015

\section{はじめに}

脊椎動物の脊椎は, 基本的な構造を少しずつ変えてそ の種によって決まった数の椎体が頭尾軸に沿って規則正 しく並んでおり，このような分節構造は “metameric segmentation”と呼ばれる。この分節構造により形態学的多 様性や機能性を獲得している。頭蓋骨も脊椎骨と同じ body plan で構築されていると古くから考元られ, 文豪で 生物学者でもあったゲーテもそのような考元を持ってい
た ${ }^{24)}$ ，骨組織のみならず，中枢神経構造の分節構造に関 しても研究され ${ }^{16) 18)}$ ，さらに血管系でも分節的な構築が 関心を集めるに至った ${ }^{10)}$ 。このような分節構築という観 点で, 中枢神経系の血管構築を概観し，その中での穿通 動脈の血管構築について解説する。

\section{脊髄の分節性}

胎生 4 週になると神経管（neural tube）が形成され， 

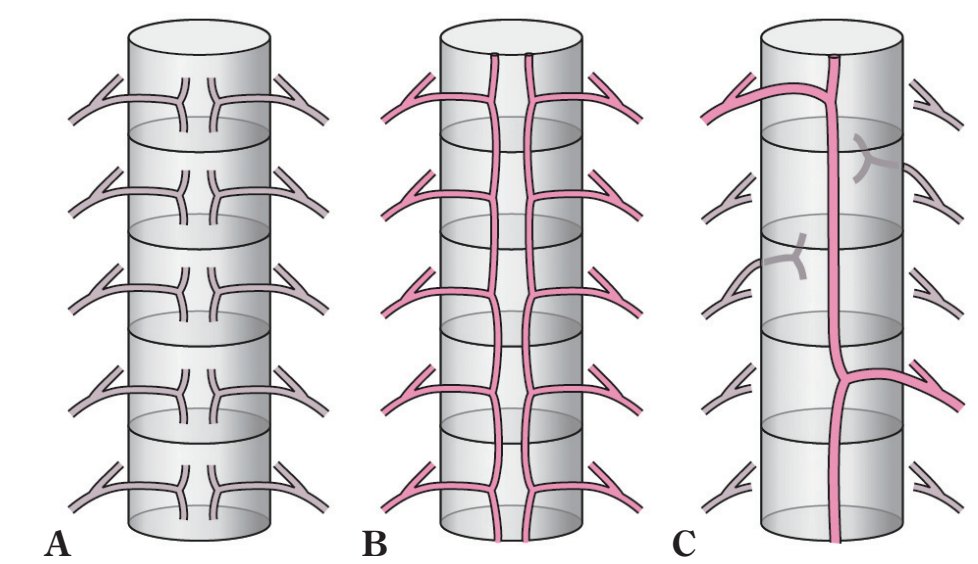

Fig. 1 Development of the segmental vascular structure of the spinal cord

A : Segmental arteries give rise to anterior radicular arteries in each myelomere bilaterally. Upper and lower branches of the radicular arteries are then formed for desegmentation.

B : Paired ventral longitudinal neural arteries are organized, and which eventually fuse to form the anterior spinal artery on the midline.

C : Many anterior radicular arteries regress, but some remain as radiculomedullary arteries.

(Reproduced from reference ${ }^{7)}$ with permission.)

この時期に䄃髄の血管系の基本構築も形成される，脊䯣 の形成において, 頭尾軸に沿った領域化は重要なプロセ スであり, 第 4 体節より頭方の神経管から脳が形成さ れ，その尾方から脊髄が形成される。繰り返す中肧葉性 の体節 (somite) は, 最も尾部の未分化の未分節中胚葉 (presomitic mesoderm) の細胞が, 後方に伸びていくと同 時に，その頭側が一定時間ごとにくびれ切られることに より形成される。この周期的な体節形成は, 転写因子の 発現振動 (oscillation)が関係しており, segmentation clock (分節時計) と呼ばれる ${ }^{15)}$. その周期はヒトでは数時間, マ ウスでは 2 時間とされ，これらの 24 時間より短い生命 周期は “ultradian oscillation” と呼ばれる. 発生初期の脊 髄では，末梢神経・骨・筋肉と同様に，血管系も分節性 に形成される。このような body plan は, 種により細か い点は異なるものの，その基本的なプロセスは脊椎動物 内でよく保存されている。 ヒトでは，この segmentation clockにより 31 個の体節が脊䯣の両側に形成され，これ に合わせ 31 対の脊髄神経, 分節動脈・静脈 (segmental artery/vein）が体節ごとに形成され，31 個の脊髄分節 (myelomere) も明らかになる（Fig. 1).

\section{菱脳と咽頭弓の分節性}

菱脳〔rhombencephalon (後脳)〕は咽頭神経が結合す
る神経管の部分であり, 古典的に 7 または 8 個の菱脳分 節（rhombomere）があり，頭尾方向に r1〜r7（8）の番 号が付けられている. 脊髄分節の数は種により異なるが, 菱脳分節の数は，種に関係なく一定である。中脳後部と 菱脳に由来する頭部神経堤細胞 (cephalic neural crest cell）は背外側経路（dorsolateral migration pathway）を 通り咽頭弓（pharyngeal arch）に侵入し，咽頭弓自身も 分節性を持っている. 咽頭神経堤細胞 (pharyngeal neural crest cell） は，菱脳分節から 3 つのルートを経由し咽頭 弓に遊走する。 三叉神経堤細胞 (trigeminal crest cell) は, r1 と r2 から, 舌骨神経堤細胞（hyoid crest cell）は r4 から, 後耳胞神経堤細胞 (postotic crest cell) は r6 と r7 から遊走する。このように神経堤細胞が付着するのは偶 数番号の菱脳分節だけであり，これに対応して咽頭神経 が形成される。つまり菱脳分節 2 つ分が 1 つの咽頭弓に 対応している $(\text { Fig. 2 })^{2)}$.

三叉神経堤細胞は，第 1 咽頭弓（顎骨弓）に遊走し, 顎骨やその筋肉・結合組織，頭蓋骨の一部，頭部の未梢 神経節などを形成し，舌骨神経堤細胞は，第 2 咽頭弓 （舌骨弓）に遊走し，舌骨，その支持組織を形成し，後耳 胞神経堤細胞は, 耳胞より尾側の咽頭弓（第 3 咽頭弓よ り尾側）に遊走し，咽頭弓骨格などに分化する。顎骨弓 には菱脳由来の神経堤細胞だけでなく, 中脳由来の神経 堤細胞も遊走しホメオボックス遺伝子群の一種である 
A

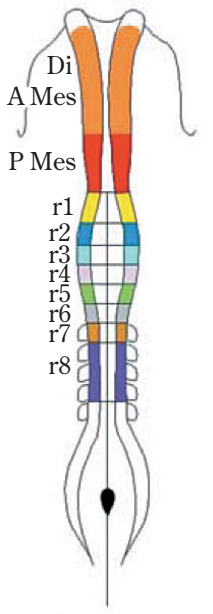

B

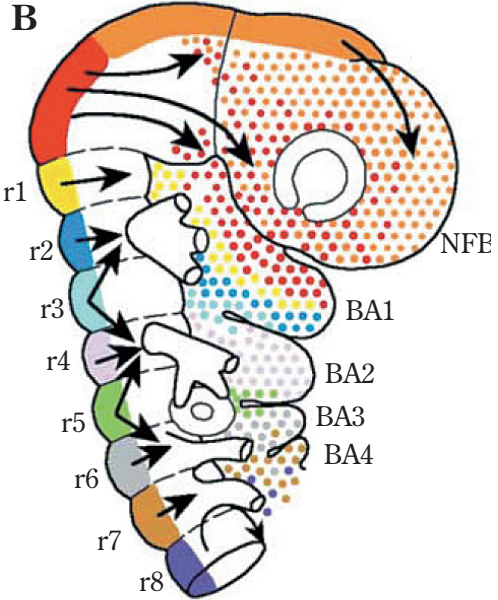

Diencephalic and anterior mesencephalic NC

Posterior mesencephalic NC

$\mathrm{r} 1 \mathrm{NC}$ $\mathrm{r} 2 \mathrm{NC}$

$\square$ r3 NC
$\square$ r4 NC

$\square$ r5 NC $\square$ r7 NC
r6 NC $\quad \square$ r8 NC

Fig. 2 The cephalic neural crest and rhombomeres

A : Presumptive diencephalic, mesencephalic and rhombencephalic territories of the neural fold in the avian embryo at the 5 somite stage.

B : Migration map of cephalic neural crest cells (NCCs) in the avian embryo. The origin of NCCs found in the nasofrontal and periocular regions and in branchial arches (BAs) are colorcoded as in A. The posterior mesencephalon participates in BA1. NCCs from r1-r2 together with a small contribution of $\mathrm{r} 3$ complete the crest-derived mesenchyme in BA1. The major contribution to the 2nd BA comes from r4. NCCs arising from $\mathrm{r} 3$ and $\mathrm{r} 5$ split to participate in the two adjacent BAs.

(Reproduced from reference ${ }^{2)}$ with permission.)

Otx2 遺伝子の支配下に顎骨弓のより腹側・遠位, つまり 下顎の形を作っている。このように顎骨弓には由来の異 なる神経堤細胞がその形作りに関与している。

\section{大脳の分節性}

大脳は, 解剖学的な基本構築として, 外套 (pallium) と外套下部（subpallium）に分けられ，前者は，内側外 套, 背側外套, 外側外套の 3 つに細分される。これらは 古典的には archipallium, neopallium, paleopallium におお む数対応する。外套下部は，線条体（striatum）と中隔 核（septum）に分けられる（Fig. 3）。大脳皮質の細胞構 築（cytoarchitecture）は，古くから Brodmann ${ }^{1)} や$ von Economo ${ }^{25)}$ らにより詳しく研究されてきた。彼らの細胞

Choroid plexus

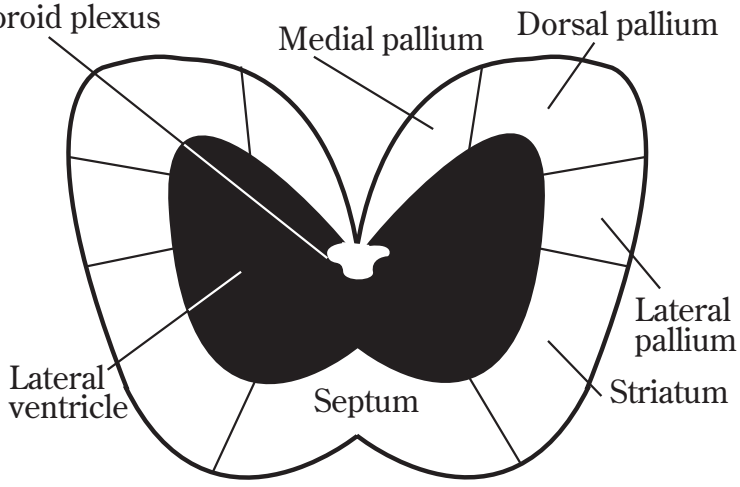

Fig. 3 Basic structure of the brain

The brain is composed of pallium and subpallium, i.e., the medial, dorsal, and lateral palliums, and striatum and septum, respectively. The medial pallium corresponds to the hippocampus and dentate gyrus, the dorsal pallium to the isocortex (neocortex) with 6-layer structure, and the lateral pallium to piriform cortex.

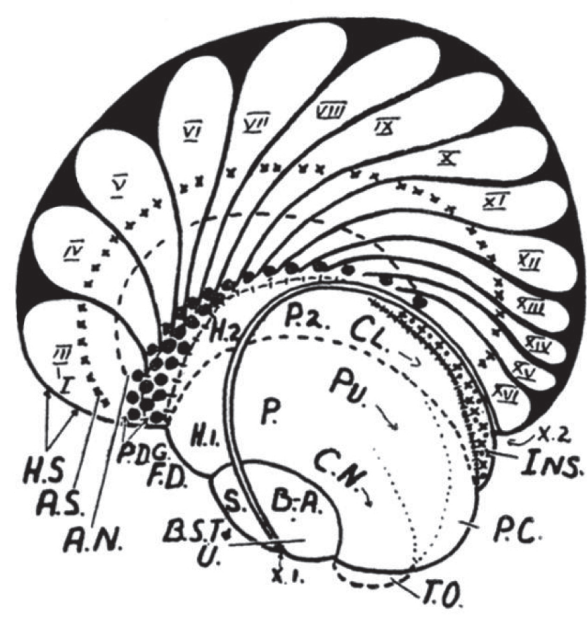

Fig. 4 Basic histogenetic units

This illustration is presented from the knowledge of comparative vertebrate anatomy and cytoarchitectures by South African physician Gerrit WH Schepers in 1948. Sixteen histogenetic units of the dorsal pallium (neopallium) are described.

(Reproduced from reference ${ }^{19)}$.)

構築による mapping と多数の制御遺伝子 (regulatory gene）により決定された組織発生単位 (histogenetic unit) は，ょく一致しており，大脳の分節性はこの組織発生単

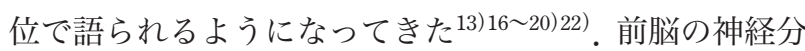
節は前脳分節（prosomere）と呼ばれ，ラットでは 6 つ の前脳分節があるとされる (Fig. 4)。この組織発生単位 は，機能的にも unit を形成しており，血管構築もこの組 
織発生単位を基本として構築され，その後 desegmentation を含めた構築の modification が起こっていると考え られる。近年は, 組織発生単位の数は, 菱脳 11 , 峡部 1 , 中脳 2 , 間脳 6 , 終脳 16 の計 36 個と考えられてお り，それぞれの組織発生単位に領域特異性の遺伝子が発 現しており, さらに神経管の背腹方向にも特異的な遺伝 子が発現している $\left(\right.$ Fig. 5) ${ }^{20)}$.

\section{脊髄レベルでの穿通動脈の解剖}

脊髄の分節単位は春髄分節と呼ばれ，この分節単位に 形成される血管構築は, 発生の進行とともに, 脱分節化 (desegmentation) し, 頭尾方向の血管構築に変化してい く. 神経管の腹側の一対の ventral longitudinal neural artery が正中で癒合し, 前脊䯣動脈 (anterior spinal artery) が形成される. 横断面での血管構築は, centrifugal (=away from the center) pattern を呈する正中・腹側の 穿通動脈〔sulcal artery (中心溝動脈) が同側の中心 $2 / 3$ を支配し， centripetal (=toward the center) pattern を呈 する脊髄周囲を取り囲む pial network〔vasa corona（軟膜 動脈叢 ) 〕が周囲の $1 / 3$ を支配する（Fig. 6).

発生学的に一対の ventral longitudinal neural artery に 左右の中心溝動脈が属するため, 中心溝動脈は一側のみ を栄養する.この基本構造が, longitudinal artery が正中 線上で笁合した後も残される。中心溝動脈の頭尾方向の 密度は，生下時には全脊䯣で一定であるが，その後の胸 髄はほかの部位より成長するため, 中心溝動脈の密度は 低くなる。このため胸髄が虚血に弱いとされる，前脊䯣
動脈は中心溝動脈のみを分枝するのではなく, 軟膜動脈 叢へも軟膜枝を分枝する. 前脊髄動脈は, 前正中裂内 ・ 軟膜下にあり, 中心溝動脈は, 各䯣節に 6 7 本, 総数 約 200 本あり，その太さは， $60 \sim 72 \mu \mathrm{m}$ で，さらに先の 髄内部分の穿通動脈は $24 \sim 60 \mu \mathrm{m}$ の太さがある ${ }^{21)}$. 中心

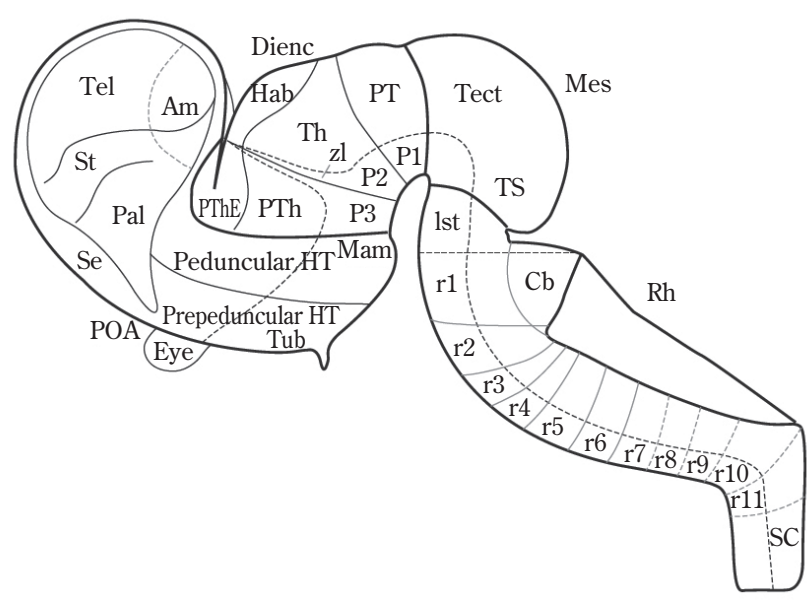

Fig. 5 Schema of the prosomeric model

The longitudinal alar-basal boundary (hatched line) is present throughout the lateral wall of the neural tube. The secondary prosencephalon consists of the telencephalon (Tel), eye and hypothalamus (HT) and the septum (Se), striatum (St), pallidum $(\mathrm{Pal})$, preoptic area $(\mathrm{POA})$, and amygdala $(\mathrm{Am})$ regions. The diencephalon consists of three prosomeres $(\mathrm{p} 1-\mathrm{p} 3)$. The rhombencephalon (Rh) contains 12 neuromeric units, from the isthmus (Ist) and rhombomere 1 down to rhombomere 11 .

Reproduced from reference ${ }^{17)}$ with permission.

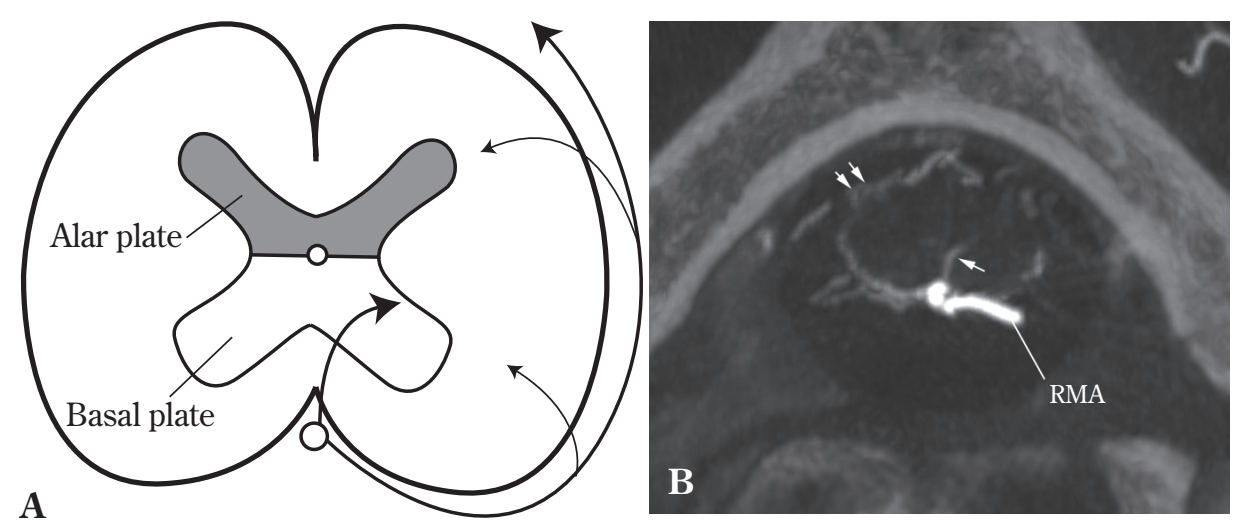

Fig. 6 Basic arterial angioarchitectures of the spinal cord

A : The ipsilateral ventral perforating artery perfuses the parenchyma centrifugally, and the peripheral dorsal perforating artery from the vasa corona perfuses centripetally.

B : Cone-beam CT of the normal spinal cord imaged by selective contrast injection to the radiculomedullary artery (RMA) in a 6-year-old boy. Single arrow indicates a sulcal artery (ventral perforating artery), and double arrows are the vasa corona. 

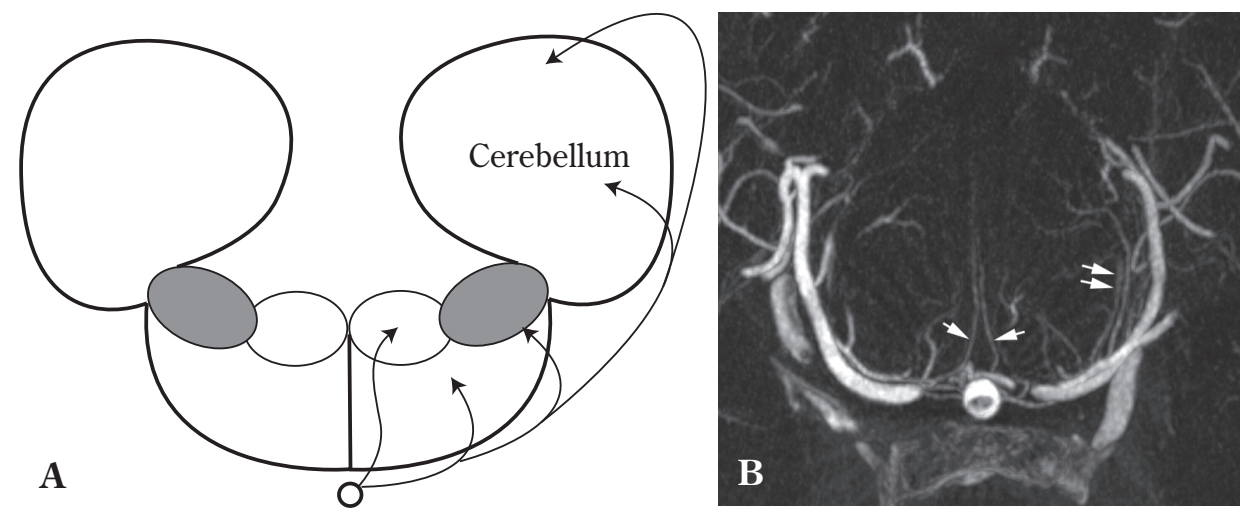

Fig. 7 Basic arterial angioarchitectures of the brain stem

A : The paramedian perforating artery perfuses the ipsilateral parenchyma centrifugally, and short/long circumferential arteries perfuse at the anteromedial and posterolateral portions centripetally. The cortical branch runs to the cerebellum.

B : Cone-beam CT of the normal brain stem imaged by selective contrast injection to the vertebral artery in a 53-year-old woman. Single arrows indicate paramedian arteries (ventral perforating artery), and double arrows mark a short circumferential artery.

溝動脈は, 脊髄実質に入る前に上行枝と下行枝を分岐し, 同側の上下の中心溝動脈と吻合する。前脊䯣動脈から 1 本の共通幹が分岐し, 前正中裂内の矢状面で, 左右の 2 本の中心溝動脈に分岐する場合もある ${ }^{23)}$ 。一方, 脊髄の 全周を取り囲む軟膜動脈叢から分岐する多数の穿通動脈

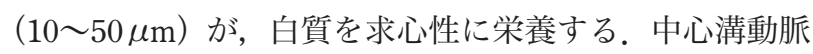
と脊髄表面からの穿通動脈の間には実質内で吻合が認め られる。

\section{脳幹レベルでの穿通動脈の解剖}

脳幹においては，椎骨動脈や脳底動脈から分岐する傍 正中動脈 (paramedian artery) は, 脊䯣の中心溝動脈に 相当する. 同様に短・長回旋動脈 (short/long circumferential artery）は, 脳幹の前内側部と後外側部の脳神経の exit/entry zone をそれぞれ栄養し, 脊䯣の軟膜動脈叢に 相当する ${ }^{11)}$ 。つまり centrifugal pattern を呈する傍正中動 脈と centripetal pattern を呈する短・長回旋動脈から構 成されている (Fig. 7)。脳幹の動脈には神経堤細胞の関 与はなく, 中肧葉性の内膜・中膜からなるが，顎顔面の 動脈や内頝動脈は，内膜は中胚葉性であるが，中膜は神 経堤細胞から形成される ${ }^{4)}$. 腹側大動脈の頭側への延長 部分や第 1 - 第 2 咽頭動脈弓の腹側部分からは，将来の 外䅡動脈となる腹側咽頭動脈 (ventral pharyngeal artery) が形成され，顎顔面の動脈となる，小脳や大脳は，発生 過程で神経管の背側の翼板（alar plate）が外側に拡張し
た脳組織と考えられ，脊髄における基本血管構造の背側 を栄養する軟膜動脈叢のさらに外側に皮質動脈が追加さ れた血管構築をとる。菱脳背側前端から分化する小脳を 栄養する動脈は，長回旋動脈にさらに外側に皮質動脈が 追加された構築である。

\section{大脳レベルでの穿通動脈の解剖}

終脳の栄養動脈は, 発生学的に一対の背側大動脈 (dorsal aorta) の頭側への延長である原始内頝動脈 (primitive internal carotid artery）から形成される。原始内䅡動脈の 内膜は中胚葉起源であるが，中膜は神経堤細胞起源であ り, 中胚葉起源の内膜・中膜からなる後方循環の動脈と Willis 動脈輪を介して, 前脳・中脳境界でつながる4)。そ の冠状断面の血管構築は, 腹側正中部の同側支配の centrifugal pattern を呈する穿通動脈 (striatal artery や thalamoperforating artery） , 背側の大脳表面の皮質動脈か ら中心に向けて栄養する centripetal pattern を呈する穿 通動脈からなり，これは脊髄の横断面の血管構築と類似 している。つまり subpallium に向かう centrifugal patternの穿通動脈と pallium に向かう centripetal pattern の穿通動脈に分けられる。このように脊髄・脳幹・大脑 の血管構築には類似性 (analogy) が認められる（Fig. 8A, B)。脳底部の穿通動脈の主幹動脈からの分岐には種々の パターンがあり，個体ごとに一定しないが，それらが脳 実質の入る前有孔質・後有孔質・中脳背面・視床後面な 

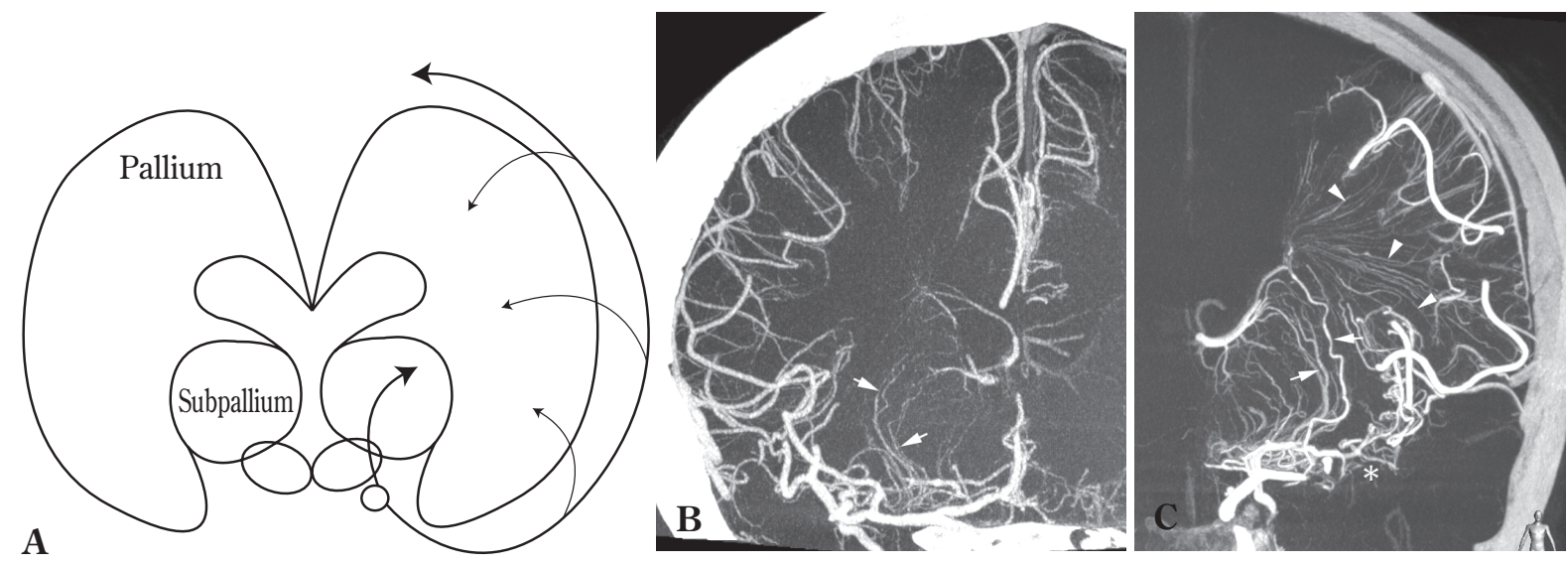

Fig. 8 Basic arterial angioarchitectures of the brain

A : The ventral perforating artery perfuses centrifugally while the dorsal perforating arteries branch off from the cortical arteries and perfuse the parenchyma centripetally.

B : Cone-beam CT of the normal brain (right cerebral hemisphere) imaged by selective contrast injection to right internal carotid artery in a 54-year-old man. Single arrows indicate the ventral perforating arteries of the right middle cerebral artery. Dorsal perforating arteries from the cortical arteries are not visible in this image.

C : Cone-beam CT of the brain (left cerebral hemisphere) with left middle cerebral artery stenosis at the M2 portion (asterisk) imaged by selective contrast injection to the left internal carotid artery in the same patient as in B. Ventral perforating arteries (arrows) supply the cortex through the recruited collateral pathway of the dorsal perforating arteries of the cortical arteries (arrowheads). Blood flow in the cortical perforating arteries is retrograde (centrifugal).

どにある perforation pit の位置には個体差は少ない26). また脈絡叢動脈から分岐し脳室から脳表に向かう centrifugal pattern の subependymal artery があるが，その支 配領域は，脳表からの ventriculopetal artery のそれとは 比較にならないほど狭い3)14)24)。

\section{大脳レベルでの狭窄・閉塞性疾患に おける穿通動脈の変化}

内頝動脈の頭蓋内の最も末梢部，つまり前方循環の前 大脳動脈と中大脳動脈分岐部を中心とする進行性閉塞疾 患にはいくつかの疾患があり, 閉塞の状況に応じて側副 路として leptomeningeal anastomosis と穿通動脈間の吻 合等が発達する。両側性に狭窄性変化を認め, 穿通動脈 による側副路が発達し，原因不明の場合には「もやもや 病」と呼ばれているが, 穿通動脈による側副路の発達の 程度はまちまちであり, まったく発達しない場合もあり, このような病態を起こす基礎疾患も, 外傷・動脈硬化を 含めDown 症候群・神経線維腫など多岐にわたる。その ため, 疾患の定義も不明瞭なもやもや病を特別な病態と して扱うのは病因論的にはあまり意味がなく ${ }^{5)}$, 前方循 環に慢性進行性狭窄・閉塞をきたす疾患群を，「Willis 動 脈輪閉塞症」と呼ぶほうが，実態に即している。つまり,
「Willis 動脈輪閉塞症」は，内頝動脈の頭蓋内の最も末梢 部の近傍に狭窄・閉塞があるが，両側性疾患である必要 もなく，原疾患の有無にも関係なく，いわゆる「もやも や血管」の発達も必ずしも必要としない.

この Willis 動脈輪閉塞症 で興味深いのは, 狭窄・閉塞 性変化をきたす動脈部分は, 発生学的に原始内頝動脈の 頭蓋内末梢部分であり，その中膜は，神経堤細胞起源で あり，そのような狭窄性の変化をきたさない ventral longitudinal neural artery からなる後方循環の動脈の中膜は 中肧葉起源であることである ${ }^{4)}$. 中大脳動脈や内頝動脈 の C1-2 部に限局した狭窄もWillis 動脈輪閉塞症に含ま れる ${ }^{9)}$.このような狭窄・閉塞性変化が, 出生前の時期 を含め，どの夕イミングでも起こる可能性があり，その 時期や個々の症例での解剖学的な血管構築の差異により 側副路の発達〔動脈新生（arteriogenesis）や穿通動脈の recruitment など」が種々の程度起こると考えられる6). 種々の trigger に反応し, 頭蓋内内頝動脈末端周囲の閉塞 性変化が起こり，局所に血管新生（angiogenesis）や動脈 新生が働く。この trigger には複数の要因があり, ホスト 側の要因も加わり，穿通動脈を主体とする側副路が形成 されると考えられる。最近，もやもや病の感受性遺伝子 として報告された遺伝子多型の RNF213 遺伝子 (p.R4810K) もこのホスト側の要因の一つと考えられる 
(Fig. 8C $)^{12)}$.

\section{おわりに}

中枢神経系は, 神経管から形成され，その分節構造は, 近年, 詳しく研究されてきた ${ }^{218)}$. 血管構築も分節性の 観点から考えることが可能である。前後軸に沿って神経 分節 (組織発生単位) があり, 個々の神経分節に背腹軸 があり，腹側から中心性の centrifugal pattern, また背側 から末梢性の centripetal pattern の穿通動脈の構築があ り，このような三次元的な血管構築で中枢神経系の血管 構築を考えることが可能である.

開示すべき COI はありません.

\section{文 献}

1) Brodmann K: Vergleichende Lokalisationslehre der Großhirnrinde. Leipzig, J. A. Barth, 1909.

2) Creuzet S, Couly G, Le Douarin NM: Patterning the neural crest derivatives during development of the vertebrate head: insights from avian studies. J Anat 207: 447-459, 2005.

3) De Reuck J: The human periventricular arterial blood supply and the anatomy of cerebral infarctions. Eur Neurol 5: 321-334, 1971.

4) Etchevers HC, Vincent C, Le Douarin NM, Couly GF : The cephalic neural crest provides pericytes and smooth muscle cells to all blood vessels of the face and forebrain. Development 128: 1059-1068, 2001.

5）小宮山雅樹：ウィリス動脈輪閉塞症の診断基準につい て. No Shinkei Geka 27:481, 1999.

6) Komiyama M: Moyamoya disease is a progressive occlusive arteriopathy of the primitive internal carotid artery. Interv Neuroradiol $\mathbf{9 : 3 9 - 4 5 , 2 0 0 3 .}$

7）小宮山雅樹：脊髄血管の機能解剖. 脊椎脊髄 21 : $972-$ 981, 2008.

8）小宮山雅樹：脳脊髄血管の基本構築。脳脊髅血管の機能 解剖 詳細版。大阪，メディカ出版，2011.

9）小宮山雅樹：若年性中大脳動脈閉塞症。小宮山雅樹編： 神経脈管学. 大阪, メディカ出版, 2012, pp.448-449.

10）倉谷 滋：かたちの進化の設計図 ゲノムから進化を考 える2. 東京，岩波書店，1997。

11) Lazorthes $G$ : Arterial vascularization of the brain stem.
Research technic and new data. Bull Acad Natl Med 149 (suppl) : 714-721, 1965. [Article in French]

12) Liu W, Morito D, Takashima S, Mineharu Y, Kobayashi H, Hitomi T, Hashikata H, Matsuura N, Yamazaki S, Toyoda A, Kikuta K, Takagi Y, Harada KH, Fujiyama A, Herzig R, Krischek B, Zou L, Kim JE, Kitakaze M, Miyamoto S, Nagata K, Hashimoto N, Koizumi A: Identification of RNF213 as a susceptibility gene for moyamoya disease and its possible role in vascular development. PLoS One 6: e22542, 2011.

13) Lumsden A, Keynes R: Segmental patterns of neuronal development in the chick hindbrain. Nature 337:424428, 1989.

14) Marinković S, Gibo H, Filipović B, Dulejić V, Piscević I: Microanatomy of the subependymal arteries of the lateral ventricle. Surg Neurol 63: 451-458, 2005.

15) Pourquie $O:$ The vertebrate segmentation clock. J Anat 199: 169-175, 2001.

16) Puelles L, Rubenstein JL: Expression patterns of homeobox and other putative regulatory genes in the embryonic mouse forebrain suggest a neuromeric organization. Trends Neurosci 16:472-479, 1993.

17) Puelles L: Forebrain development: prosomere model. in Squire LR (ed) : Encyclopedia of Neuroscience. Massachusetts, Academic Press, Elsevier, 2009, pp.315-319.

18) Rubenstein JL, Martinez S, Shimamura K, Puelles L: The embryonic vertebrate forebrain: the prosomeric model. Science 266: 578-580, 1994.

19) Scheper GWH:Evolution of the Forebrain: The Fundamental Anatomy of the Telencephalon. Cape Town, Maskew Miller, 1948, p.212.

20) Schuurmans C, Guillemot F: Molecular mechanisms underlying cell fate specification in the developing telencephalon. Curr Opin Neurobiol 12:26-34, 2002.

21) Suh TH, Alexander L: Vascular system of the human spinal cord. Arch Neurol Psychiat 41: 659-677, 1939.

22）田中三千裕：ヒト大脳皮質の細胞構築と脳血管機能解 剖。小宮山雅樹編：脳脊髄血管一正常から変異，異常ま で：ニッチ脳神経脈管カンファレンス精選集，大阪，メ ディカ出版, 2014, pp.39-52.

23) Turnbull IM: Microvasculature of the human spinal cord. J Neurosurg $35:$ 141-147, 1971.

24) Van den Bergh $\mathrm{R}$ : Centrifugal elements in the vascular pattern of the deep intracerebral blood supply. Angiology 20: 88-94, 1969.

25) von Economo C: Zellaufbau der Grosshirnrinde des Menschen; Zehn Vorlesungen. Berlin, Springer, 1927.

26) Yasargil MG: Microneurosurgey Vol 1. New York, Thieme, 1984. 
脳・脊鹃有の穿通動脈の機能解剖一中枢神経系の分節構築の観点から一

小宮山雅樹

中枢神経組織は, 前後軸に沿って, 分節性に神経分節 (neuromere) から形成されている. 脊髄は, 中胚葉性の体節（somite）を中心に種に特有な数の脊蹎分節からなるが, 菱脳は種に関係なく 7 8 個の菱脳分節（rhombomere）からなる. 古典的な大脳の細胞構築 (cytoarchitecture) は, 個々の神 経分節特有の遺伝子発現により規定される組織発生単位 (histogenetic unit) を基本に構築されている ことが明らかになり，血管構築もそれを基本に構築されていることが明らかになってきた.

脊髄・脳幹・大脳レベルにおける動脈灌流のパターンは, 脊髄・脳幹では横断面において, 大脳で は冠状断面において, 中心性の穿通動脈は, 腹側正中から一側性に末梢に向かう centrifugal pattern をとり, 末梢性の穿通動脈は, 背側・表面から中心に向かう centripetal pattern をとっている.この centrifugal/centripetal patterns は個々の histogenetic units の中で基本的血管構築と考えられる.

脳外誌 $24: 4-11,2015$ 